\title{
Evaluation of Physical and Mechanical Properties of Particleboard Made from Petung Bamboo Using Sucrose-based Adhesive
}

\begin{abstract}
Ragil Widyorini
Bamboo is a potential non-wood lignocellulosic material from which to make particleboard. Sucrose-based adhesive is another potential ingredient, but its use in particleboard has been limited. Addition of ammonium dihydrogen phosphate (ADP) can be used to increase the bonding ability of sucrose-based adhesive and to reduce the required pressing temperature. Therefore, this research used different pressing temperatures and sucrose/ammonium dihydrogen phosphate (ADP) composition ratios to optimize the properties of particleboards. The physical and mechanical properties of the boards were analyzed and compared with the JIS A 5908 (2003) standard for particleboard. The results showed that the interaction of the sucrose-ADP composition ratio and the pressing temperature significantly affected the physical and mechanical properties of the particleboards. The particleboard using only sucrose as adhesive had optimum properties at $200{ }^{\circ} \mathrm{C}$; however, after addition of ADP, the intended properties could be achieved at a $160{ }^{\circ} \mathrm{C}$ pressing temperature.
\end{abstract}

Keywords: Petung bamboo; Sucrose; Ammonium dihydrogen phosphate; Particleboard; Pressing temperature

Contact information: Department of Forest Product Technology, Faculty of Forestry, Universitas Gadjah Mada, Jl. Agro no. 1, Yogyakarta, Indonesia 55281; e-mail: rwidyorini@ugm.ac.id

\section{INTRODUCTION}

Bamboo is a lignocellulosic material with great potential, especially in tropical countries, as it is a fast-growing species that starts yielding harvestable material within three or four years of planting. Bambusoideae (bamboos) comprises 1,439 described species in 116 genera (Bamboo Phylogeny Group 2012). China has the greatest bamboo diversity in Asia, with more than 500 species, followed by India, Indonesia, Myanmar, and Malaysia (Nirala et al. 2017). In Indonesia, there are 145 bamboo species, of which 63 have economic potential (Widjaja 2000).

In recent years, bamboo has become a main substitute material for wood in construction, parquets, and laminations (Mahdavi et al. 2012; Huang et al. 2013; Chen et al. 2014; Ni et al. 2016). One potential type of bamboo for use in materials is petung bamboo, which is found in Indonesia. Its characteristics include a wall thickness of $25 \mathrm{~mm}$ to $41 \mathrm{~mm}$, internode lengths of $40 \mathrm{~cm}$ to $60 \mathrm{~cm}$, and a diameter that can reach $200 \mathrm{~mm}$ (Kusumaningtyas et al. 2016). According to Laemlaksakul and Kaewkuekool (2006) and Laemlaksakul (2010), the conversion of bamboo into bamboo strips has an average potential output of up to $34.3 \%$. 
Although the potential utilization as laminates is relatively low, the remaining portion could be used as particleboard material (Laemlaksakul 2010; Widyorini et al. 2016a). The utilization of biomass byproducts from the bamboo processing industry is yet another way to support environmental sustainability.

In addition to the lignocellulosic material, an important factor in the development of environmentally friendly composites is the adhesive. Synthetic, formaldehyde-based adhesives are mostly used in the composite industry. Urea-formaldehyde is widely used as an adhesive in the manufacture of wood-based composite panels because it is colorless, fast-curing, and inexpensive (Jeong and Park 2019). However, formaldehyde, which is a human carcinogen and not renewable, is emitted during the production and use of such composites. Therefore, many efforts have been made to develop low-formaldehydeemission synthetic resins or, even, natural adhesives. Many natural adhesives have been studied for composite products, including starch, sucrose, glucose, chitosan, lignin-tannin, tannin, tannin-sucrose, protein, gum, and citric acid (Yang et al. 2006; Umemura et al. 2009; Lei et al. 2010; Moubarik et al. 2010; Bertaud et al. 2012; Tondi et al. 2012; Umemura et al. 2012; Lamaming et al. 2013; Norström et al. 2014; Widyorini et al. 2016a; Sun and Zhao 2018; Zhao et al. 2018; Sun et al. 2019a; Zhao et al. 2019a).

Saccharide-based adhesives have potential for composite products. Lamaming et al. (2014) showed that addition of sucrose could increase the physical and mechanical properties of binderless particleboard made from oil palm trunk. Sucrose, a saccharide, can react well with citric acid (Umemura et al. 2013; Sun et al. 2019a; Zhao et al. 2019a) and tannin (Zhao and Umemura 2014; Sun and Zhao 2018) to produce good bondability in wood composite products. Widyorini et al. (2016b) showed that sucrose adhesive was affected significantly by pressing temperature. Recently, Umemura et al. (2017) found that, with the combined presence of ammonium dihydrogen phosphate (ADP) as a phosphate catalyst and a heating treatment, the resulting sucrose was transformed into a highly waterresistant substance. The substance contains a furan ring and carbonyl group that are predicted to contribute to its bondability as an adhesive for composites. Moreover, 5hydroxymethyl-2-furfural (5-HMF) is considered to be one of the most important sucrosederived products responsible in the bonding mechanism of sucrose-based adhesive. Zhao et al. (2019b) stated that the main reactions during the curing process were considered as the dehydration condensation of furan compounds and Maillard reaction. The resulting substance is mainly composed of polyfuran and linked by $\mathrm{C}-\mathrm{O}-\mathrm{C}$ and $\mathrm{C}=\mathrm{N}-\mathrm{C}$ linkages. In addition, Zhao et al. (2018) showed that application of ADP in sucrose-based adhesive in the manufacturing of recycled wood particleboard is optimal at $15 \mathrm{wt} \%$. Addition of ADP until $10 \mathrm{wt} \%$ in the manufacturing of binderless board improved the board properties and changed water-soluble components of oil palm trunk to water-insoluble components (Komariah et al. 2019). Application of sucrose-ammonium dihydrogen phosphate adhesives with a high solids content and suitable viscosities in plywood manufacturing operations was developed by Zhao et al. (2019b), Sun et al. (2019b), and Zhao et al. (2020).

This research evaluated properties of particleboard made from petung bamboo using sucrose and ADP with varying compositions and pressing temperatures. Bamboo has different characteristics compared with woody materials. This research supports the optimization of the application of sucrose and ADP in the manufacturing of non-wood particleboard and the corresponding bonding properties. 


\section{EXPERIMENTAL}

\section{Materials}

Bamboo petung particles were collected from bamboo-sawing industry in Yogyakarta province, Indonesia. The particles were then screened with a 10-mesh screen, keeping those particles that passed through. The distributions of particle sizes were $75.1 \%$ passed through 10 mesh and retained at 40 mesh (10 to 40 mesh), 14.8\% (40 to 60 mesh), and $10.1 \%$ passed through 60 mesh. After screening, the particles were then kept until they were air-dried (at around $12.3 \% \pm 0.34 \%$ ).

Sucrose (Meade-King, Robinson \& Co. Ltd., Liverpool, UK) and ammonium dihydrogen phosphate (Merck, Darmstadt, Germany) was used without further purification.

\section{Methods}

Preparation of adhesive solution

The sucrose and ADP were dissolved in distilled water at various compositions, and the concentration of solution was set at $50 \mathrm{wt} \%$. The mixture ratios of sucrose/ADP were set at $100 \mathrm{wt} \%$ / $0 \mathrm{wt} \%, 95 \mathrm{wt} \%$ / $5 \mathrm{wt} \%, 90 \mathrm{wt} \% / 10 \mathrm{wt} \%, 85 \mathrm{wt} \% / 15 \mathrm{wt} \%$, and $80 \mathrm{wt} \% / 20 \mathrm{wt} \%$. The adhesive load was $20 \mathrm{wt} \%$ based on dry-weight particles. The weight of particles was calculated from the target density of the particleboard $\left(0.8 \mathrm{~g} / \mathrm{cm}^{3}\right)$, with the target dimensions of the board being $25 \mathrm{~cm} \times 25 \mathrm{~cm} \times 1 \mathrm{~cm}$.

\section{Manufacture of particleboard}

The adhesive solution was sprayed onto the particles, which were then oven-dried at $80{ }^{\circ} \mathrm{C}$ for $4 \mathrm{~h}$ to reduce the moisture content of the particles. The moisture content of the sprayed particles was $26 \% \pm 0.33 \%$, and it decreased to $5 \% \pm 0.34 \%$ after oven-drying. The particles were hand-formed into $25-\mathrm{cm} \times 25-\mathrm{cm}$ mats and then hot-pressed (PCL-700, Riken Seiki Co., Ltd., Ojiya, Japan) using a three-step cycle as done by Widyorini et al. (2018) at $3 \mathrm{MPa}$ specific pressure. The target thickness was set at $10 \mathrm{~mm}$. The mat was hot-pressed for $5 \mathrm{~min}$, followed by $1 \mathrm{~min}$ for the breathing stage, and then hot-pressed again for $5 \mathrm{~min}$, for a total pressing time of $10 \mathrm{~min}$. The pressing temperatures used were $160{ }^{\circ} \mathrm{C}, 180{ }^{\circ} \mathrm{C}$, and $200{ }^{\circ} \mathrm{C}$.

\section{Evaluation of board properties}

The particleboards were conditioned at room temperature for approximately 1 week, and then their physical and mechanical properties were evaluated according to the Japanese Industrial Standard for particleboard (JIS A 5908 2003). Surface roughness was also evaluated as a means of characterizing the surface quality.

The thickness swelling (TS), water absorption (WA), and internal bonding strength (IB) tests were performed on $5 \mathrm{~cm} \times 5 \mathrm{~cm} \times 1 \mathrm{~cm}$ specimens. Thickness swelling and WA were tested by immersing the specimens in water at room temperature for $24 \mathrm{~h}$. The thickness and the weight changes of the specimens that occurred throughout the treatments were then determined. Internal bonding strength was tested by pulling the specimen perpendicularly to its surfaces at a loading speed of $2 \mathrm{~mm} / \mathrm{min}$ using a universal testing machine (Model 3360, Instron, Norwood, MA, USA).

The static three-point bending strengths under dry and wet conditions were performed on $20 \mathrm{~cm} \times 5 \mathrm{~cm} \times 1 \mathrm{~cm}$ specimens from each specimen. The modulus of rupture (MOR) and modulus of elasticity (MOE) were calculated from the bending test. The 
effective span and the loading speed were $15 \mathrm{~cm}$ and $10 \mathrm{~mm} / \mathrm{min}$, respectively. The same test was performed for the wet bending strength evaluation (test B) of the specimen after immersion in boiling water for $2 \mathrm{~h}$ and further immersion in room temperature water for 1 $\mathrm{h}$. Before the wet bending test, the surface roughness was measured as average roughness $\left(R_{\mathrm{a}}\right)$ using a surface roughness tester (SRG 400, Bosworth Instrument, Cleveland, $\mathrm{OH}$, USA) at six random points. The specimen size for the screw-holding power tests of the boards was $10 \mathrm{~cm} \times 5 \mathrm{~cm} \times 1 \mathrm{~cm}$. The pulling-out load speed was approximately $2 \mathrm{~mm} / \mathrm{min}$. The MOR, MOE, and IB values were then corrected for target density based on the specimen densities. Each experiment was performed three times, and the average values and standard deviations were calculated. The data were then statistically analyzed using a two-way analysis of variance, followed by Tukey's honestly significant difference (HSD) test.

\section{RESULTS AND DISCUSSION}

All of the particleboards were successfully produced. The color of the boards became darker with increasing ADP content and pressing temperature. The moisture content of the particleboards ranged from $5.35 \%$ to $9.08 \%$. Table 1 shows the analysis of variance of the factors corresponding to each board property. Clearly, the interaction of the pressing temperature and the sucrose/ADP ratio significantly affected all of the board properties. During heat treatment, ammonium catalyzed the hydrolysis of sucrose to glucose and fructose, and the ammonium ion from ADP also was hydrolyzed to ammonium hydroxide (Zhao et al. 2019b). It has been found that there was a positive correlation between the temperature and curing of sucrose/ADP (Zhao et al. 2020), and those combinations affected board properties. The interaction analysis is important for predicting the optimum manufacturing condition of the board, considering that the board properties were simultaneously affected by many factors. In addition, Zhao et al. (2018) showed significant effects for each factor, i.e., pressing temperature and sucrose/ADP ratio.

Table 1. Analysis of Variance

\begin{tabular}{|c|c|c|c|}
\hline \multirow[b]{2}{*}{ Board Property } & \multicolumn{3}{|c|}{ Significance of Factors } \\
\hline & $\begin{array}{c}\text { Pressing } \\
\text { Temperature }\end{array}$ & $\begin{array}{c}\text { Sucrose/ADP } \\
\text { Ratio }\end{array}$ & $\begin{array}{c}\text { Pressing Temperature*Sucrose/ADP } \\
\text { Ratio }\end{array}$ \\
\hline TS & $1.4 \times 10^{-14}$ ** & $3.7 \times 10^{-17 * *}$ & $1.7 \times 10^{-13 * *}$ \\
\hline WA & $5.2 \times 10^{-17 * *}$ & $8.2 \times 10^{-22 * *}$ & $3.7 \times 10^{-16 * *}$ \\
\hline Surface roughness & $1.6 \times 10^{-13 * *}$ & $5.8 \times 10^{-10 * *}$ & $1.1 \times 10^{-13 * *}$ \\
\hline MOR & $1.4 \times 10^{-11 * *}$ & $5.1 \times 10^{-12 * *}$ & $9.1 \times 10^{-15 * *}$ \\
\hline MOE & $1.5 \times 10^{-16 * *}$ & $4.2 \times 10^{-21 * *}$ & $3.9 \times 10^{-17}$ ** \\
\hline $\mathrm{IB}$ & $3.0 \times 10^{-9 * *}$ & $3.3 \times 10^{-12 * *}$ & $1.0 \times 10^{-6 * *}$ \\
\hline Screw holding strength & $1.6 \times 10^{-7 \star *}$ & $1.2 \times 10^{-10 * *}$ & $1.8 \times 10^{-7 * *}$ \\
\hline${ }^{\star \star}$ Significant at $p<0.01$ & & & \\
\hline
\end{tabular}

After conditioning, the thickness of particleboards that used only pure sucrose as an adhesive and pressed at $160{ }^{\circ} \mathrm{C}$ was $1.18 \pm 0.03 \mathrm{~cm}$ or increased around $18 \%$ compared to targeted thickness. The boards looked not as dense as other boards, since the densities of those particleboards were only $0.64 \pm 0.02 \mathrm{~g} / \mathrm{cm}^{3}$. It seemed that the bondability of the boards was lower compared to other boards. Figure 1 shows the conditions of particleboards before and after water immersion for $24 \mathrm{~h}$ at room temperature. The color 
of particleboards became more darker after water immersion. Interestingly, all of the particleboards were not destroyed during water immersion test.

Figure 2 shows the TS and WA of the sucrose-ADP-based particleboard made from bamboo. When only sucrose was used as an adhesive, and the board was pressed at 160 ${ }^{\circ} \mathrm{C}$, the TS of the board was $60 \%$ based on the thickness after conditioning or $91 \%$ based on the target thickness. The average TS values of the boards decreased to $18 \%$ at a pressing temperature of $180{ }^{\circ} \mathrm{C}$, indicating that increasing pressing temperature contributed to the improvement of bonding performance of the board. Compared to Widyorini et al. (2016a), binderless particleboard made from petung bamboo has a TS value $35 \%$ when it pressed at $180{ }^{\circ} \mathrm{C}$. Lamaming et al. (2014) showed that the TS values of old and young oil palm trunk binderless particleboards that pressed at $180{ }^{\circ} \mathrm{C}$ were $39.6 \%$ and $22.7 \%$ and decreased to $15.2 \%$ and $15.9 \%$, respectively, after addition of $20 \mathrm{wt} \%$ of sucrose. It has been stated by Lamaming et al. (2013) that the particleboard made with the addition of sucrose consisted of short chain polymers with a large amount of branching with other monosaccharides, that it might possibly to contribute to its bondability. Other results from Widyorini et al. (2016b) showed that the TS of boards made from teak wood was $62 \%\left(180{ }^{\circ} \mathrm{C}\right)$ with the same adhesive. Those results were better than that of Zhao et al. (2018), in which the particleboard sample made from recycled wood and sucrose adhesive pressed at $180{ }^{\circ} \mathrm{C}$ could not be measured due to its destruction. It seemed that the chemical components of raw material also affected the board properties. In addition, if only sucrose is used as the adhesive and a pressing temperature of at least $200{ }^{\circ} \mathrm{C}$, the particleboard made from bamboo has TS value of $11.7 \pm 2.2 \%$, that approached value for the requirement of JIS A 5908 (2003).
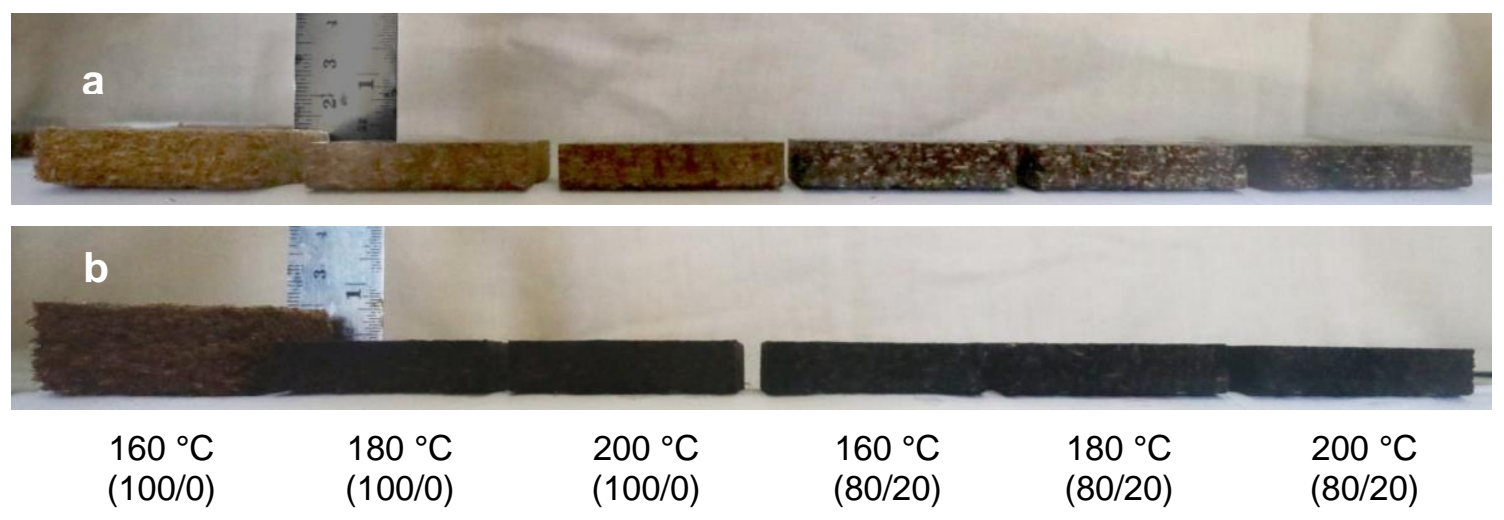

Fig. 1. Conditions of particleboards at various pressing temperature and sucrose/ADP ratios, before (a) and after (b) water immersion for $24 \mathrm{~h}$ at room temperature

Figure 2 shows that, with the addition of at least $5 \mathrm{wt} \%$ of ADP and pressing temperatures of $180{ }^{\circ} \mathrm{C}$, the TS values of the boards were less than $12 \%$. Interestingly, with the addition of at least $15 \mathrm{wt} \%$ of ADP, the average TS values of the boards met the requirement of JIS A 5908 (2003) even when pressed at $160{ }^{\circ} \mathrm{C}$. The addition of ADP noticeably reduced the required pressing temperature for producing boards that met the TS standard. Compared to Zhao et al (2018), at the same temperature and sucrose/ADP ratio, the TS of particleboards made from recycled wood was around 26 to $27 \%$. This result is supported by Umemura et al. (2017), in the presence of $5 \mathrm{wt} \%$ of ADP, the sucrose reached insolubility more than $40 \%$ at heating temperatures of $160{ }^{\circ} \mathrm{C}$ or more. In addition, the insoluble matter rate increased with increasing temperature with different trends for each 
sucrose/ADP ratio, indicating that sucrose was polymerized to a highly water-resistant substance with heating and the presence of ADP as a catalyst. Based on the Zhao et al. (2018), the insoluble mass proportion of sucrose-ADP adhesive (85/15 wt\%) after boiling treatment for $4 \mathrm{~h}$ was increased, exceeded $60 \%$ when the heating temperature was or more than $160{ }^{\circ} \mathrm{C}$ for $10 \mathrm{~min}$. Based on thermal analysis, this indicated that the main curing behavior of SADP adhesive occurred near $145^{\circ} \mathrm{C}$ and the majority of SADP seemed have already cured at these temperatures ( 150 to $170{ }^{\circ} \mathrm{C}$ ) (Zhao et al. 2020).
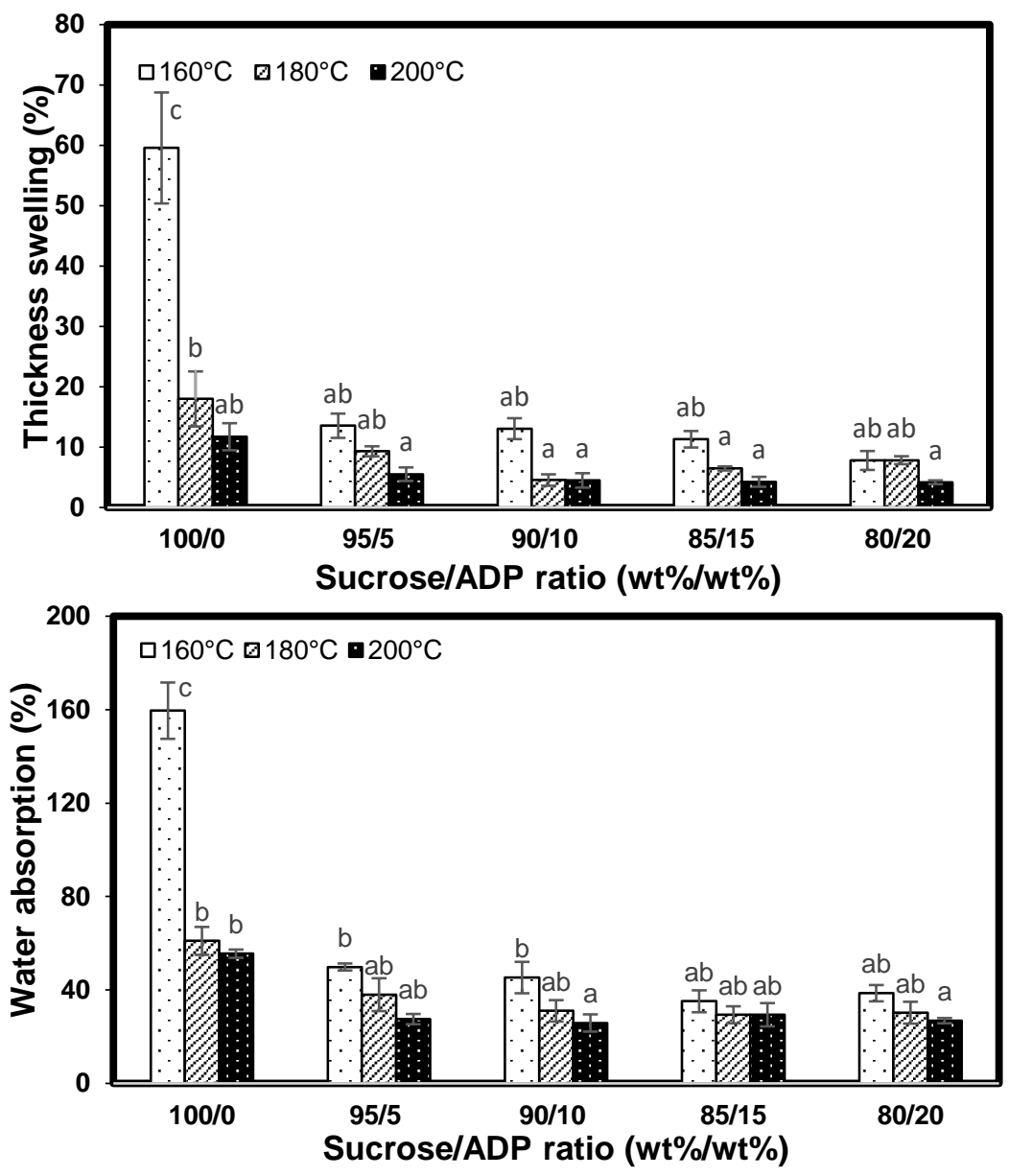

Fig. 2. TS and WA of sucrose-based particleboards made from bamboo. Error bars indicate the standard deviations. Different letters indicate significant differences between factors at $p<0.01$.

The same trend was found for the WA of the particleboards. All particleboards had WA values less than $60 \%$, except for those particleboards that used only sucrose as adhesive and were pressed at $160{ }^{\circ} \mathrm{C}(160 \%)$ or $180{ }^{\circ} \mathrm{C}(61 \%)$. The same results were found by Lamaming et al. (2014); the WA values of old and young oil palm trunk particleboards that were bonded with sucrose and pressed at $180{ }^{\circ} \mathrm{C}$ were $59.9 \%$ and $56.18 \%$, respectively. Based on Table 1 and Fig. 2, this research clearly showed that the interaction between sucrose/ADP ratio and pressing temperature significantly affected the TS and WA values of the bamboo boards. Increasing the ADP portion of the sucrose/ADP ratio decreased the required pressing temperature for achieving optimum board properties.

Table 2 shows the average surface roughness $\left(R_{\mathrm{a}}\right)$ values of the particleboards made from bamboo. Surface roughness is an important point in determining the quality of final 
products, especially when the particleboard is used for thin overlays in the wood manufacturing industry. In this research, $R_{\mathrm{a}}$ ranged from $7.43 \mu \mathrm{m} \pm 0.31 \mu \mathrm{m}$ to $17.33 \mu \mathrm{m}$ $\pm 1.87 \mu \mathrm{m}$, which is greater than that of commercially manufactured composite board (Hiziroglu and Suzuki 2007). The particleboard that used only sucrose as adhesive and was pressed at $160{ }^{\circ} \mathrm{C}$ had a rough surface. This result was consistent with the TS and WA values and indicated that the sucrose had not yet polymerized at $160{ }^{\circ} \mathrm{C}$, as mentioned by Umemura et al. (2017). However, increasing the pressing temperature and fraction of ADP simultaneously significantly affected the surface roughness of the boards. Compared to commercial particleboard made from rubber wood (Hiziroglu et al. 2004), the particleboard made using sucrose/ADP (90 wt $\%$ / $10 \mathrm{wt} \%$ ) with a pressing temperature of $180{ }^{\circ} \mathrm{C}$ had a smoothest surface. The degree of surface roughness is affected by raw material characteristics (such as particle size, species, and fiber distribution) and manufacturing variables (such as pressing parameters, adhesive content, densification of face layers, and sanding) (Hiziroglu and Suzuki 2007).

Table 2. Surface Roughness, MOR, MOE, and Screw Holding Strength of the Sucrose/ADP-based Particleboard

\begin{tabular}{|c|c|c|c|c|c|}
\hline $\begin{array}{c}\text { Pressing } \\
\text { Temperature } \\
\left({ }^{\circ} \mathrm{C}\right)\end{array}$ & $\begin{array}{c}\text { Sucrose/ADP } \\
\text { Ratio } \\
\text { (wt\%/wt } \% \text { ) }\end{array}$ & $\begin{array}{c}R_{\mathrm{a}} \\
(\mu \mathrm{m})\end{array}$ & $\begin{array}{c}\text { MOR } \\
\text { (MPa) }\end{array}$ & $\begin{array}{l}\mathrm{MOE} \\
\text { (GPa) }\end{array}$ & $\begin{array}{l}\text { Screw Holding } \\
\text { Strength } \\
\text { (N) }\end{array}$ \\
\hline \multirow{5}{*}{160} & $100 / 0$ & $17.33 \pm 1.87^{c}$ & $0.78 \pm 0.03^{a}$ & $0.15 \pm 0.01^{a}$ & $52 \pm 5^{a}$ \\
\hline & $95 / 5$ & $11.33 \pm 0.90^{b}$ & $13.97 \pm 0.02^{b}$ & $3.76 \pm 0.02^{c}$ & $393 \pm 8^{b}$ \\
\hline & $90 / 10$ & $11.35 \pm 0.97^{b}$ & $12.21 \pm 1.77^{b}$ & $3.51 \pm 0.27^{b c}$ & $385 \pm 47^{b}$ \\
\hline & $85 / 15$ & $8.42 \pm 0.86^{\mathrm{ab}}$ & $12.47 \pm 0.94^{b}$ & $3.32 \pm 0.12^{b c}$ & $400 \pm 16^{b}$ \\
\hline & $80 / 20$ & $9.58 \pm 1.79^{b}$ & $12.59 \pm 0.97^{b}$ & $3.74 \pm 0.29^{c}$ & $400 \pm 98^{b}$ \\
\hline \multirow{5}{*}{180} & $100 / 0$ & $8.50 \pm 0.84^{\mathrm{ab}}$ & $13.46 \pm 0.23^{b}$ & $3.11 \pm 0.28^{b}$ & $330 \pm 49^{b}$ \\
\hline & $95 / 5$ & $8.48 \pm 0.75^{\mathrm{ab}}$ & $14.32 \pm 0.76^{b}$ & $4.20 \pm 0.15^{c}$ & $412 \pm 10^{b}$ \\
\hline & $90 / 10$ & $7.43 \pm 0.31^{\mathrm{a}}$ & $13.44 \pm 0.78^{b}$ & $3.95 \pm 0.11^{c}$ & $442 \pm 44^{b}$ \\
\hline & $85 / 15$ & $9.18 \pm 0.92^{\mathrm{ab}}$ & $13.13 \pm 0.66^{b}$ & $3.65 \pm 0.14^{b c}$ & $401 \pm 14 b$ \\
\hline & $80 / 20$ & $9.60 \pm 1.35^{b}$ & $12.61 \pm 1.05^{b}$ & $3.73 \pm 0.14^{c}$ & $416 \pm 55^{b}$ \\
\hline \multirow{5}{*}{200} & $100 / 0$ & $10.03 \pm 0.95^{b}$ & $13.75 \pm 0.28^{b}$ & $3.36 \pm 0.07^{b c}$ & $384 \pm 16^{b}$ \\
\hline & $95 / 5$ & $9.32 \pm 0.64^{\mathrm{ab}}$ & $14.08 \pm 1.12^{b}$ & $4.14 \pm 0.07^{c}$ & $433 \pm 58^{b}$ \\
\hline & $90 / 10$ & $9.48 \pm 2.02^{\mathrm{ab}}$ & $12.23 \pm 0.11^{b}$ & $3.68 \pm 0.19^{c}$ & $455 \pm 38^{b}$ \\
\hline & $85 / 15$ & $10.83 \pm 1.80^{b}$ & $12.66 \pm 0.43^{b}$ & $3.88 \pm 0.14^{c}$ & $425 \pm 28^{b}$ \\
\hline & $80 / 20$ & $9.44 \pm 1.30^{\mathrm{b}}$ & $13.83 \pm 0.98^{b}$ & $3.84 \pm 0.10^{c}$ & $418 \pm 34^{b}$ \\
\hline
\end{tabular}

The MOR values are shown in Table 2 . The particleboard with only sucrose as adhesive and pressed at $160{ }^{\circ} \mathrm{C}$ had the lowest MOR $(0.78 \pm 0.03 \mathrm{MPa})$. Interestingly, when the pressing temperature increased, the MOR increased dramatically to greater than $13 \mathrm{MPa}$, as required for JIS A 5908 (2003) type 13. The MOR of young and old oil palm trunks particleboards with the addition of $20 \%$ sucrose and pressed at $180{ }^{\circ} \mathrm{C}$ also passed the requirement for type 13 (Lamaming et al. 2014). At the same pressing temperature, sucrose-based particleboard made from recycled wood had MOR of $1.17 \mathrm{MPa}$ (Zhao et al. 2018). This indicated that the chemical components of the raw materials also influenced the bonding properties of the sucrose-based particleboards. When ADP was added to the sucrose, the MOR values were more than $12 \mathrm{MPa}$, with half of the particleboards meeting the requirement of JIS A 5908 (2003) type 13.

The same trend was also found for the MOE values. In addition, except for that with the sucrose-only adhesive, all of the particleboards in this research had MOE values 
greater than $3 \mathrm{GPa}$, meeting the requirement of JIS A 5908 (2003) type 18. Zhao et al. (2018) found the same result, whereby the MOE exhibited a rising trend as the ADP content was increased by 5 to $15 \mathrm{wt} \%$ when pressed at $180{ }^{\circ} \mathrm{C}$. In addition, when the pressing temperature equal or more than $160{ }^{\circ} \mathrm{C}$ and the $\mathrm{ADP}$ content was $15 \%$, the mechanical properties of the particleboard made from recycle wood fulfilled the requirement of JIS A 5908 type 18.

As its MOR and MOE values were very low, the specimen of particleboard that used only sucrose as adhesive and was pressed at $160{ }^{\circ} \mathrm{C}$ was destroyed after the boiling treatment for $2 \mathrm{~h}$, as shown in Fig. 3. This result was consistent with the TS and WA values of the boards and indicated that, with only sucrose used as adhesive, greater pressing temperatures were needed to cause adhesive curing. Based on Zhao et al. (2018), insoluble materials of heated sucrose were hardly observed after boiling treatment for $4 \mathrm{~h}$, irrespective of heating temperature. However, in this research, results for wet bending strength after boiling treatment for $2 \mathrm{~h}$ were still obtained at pressing temperatures of at least $180{ }^{\circ} \mathrm{C}$.
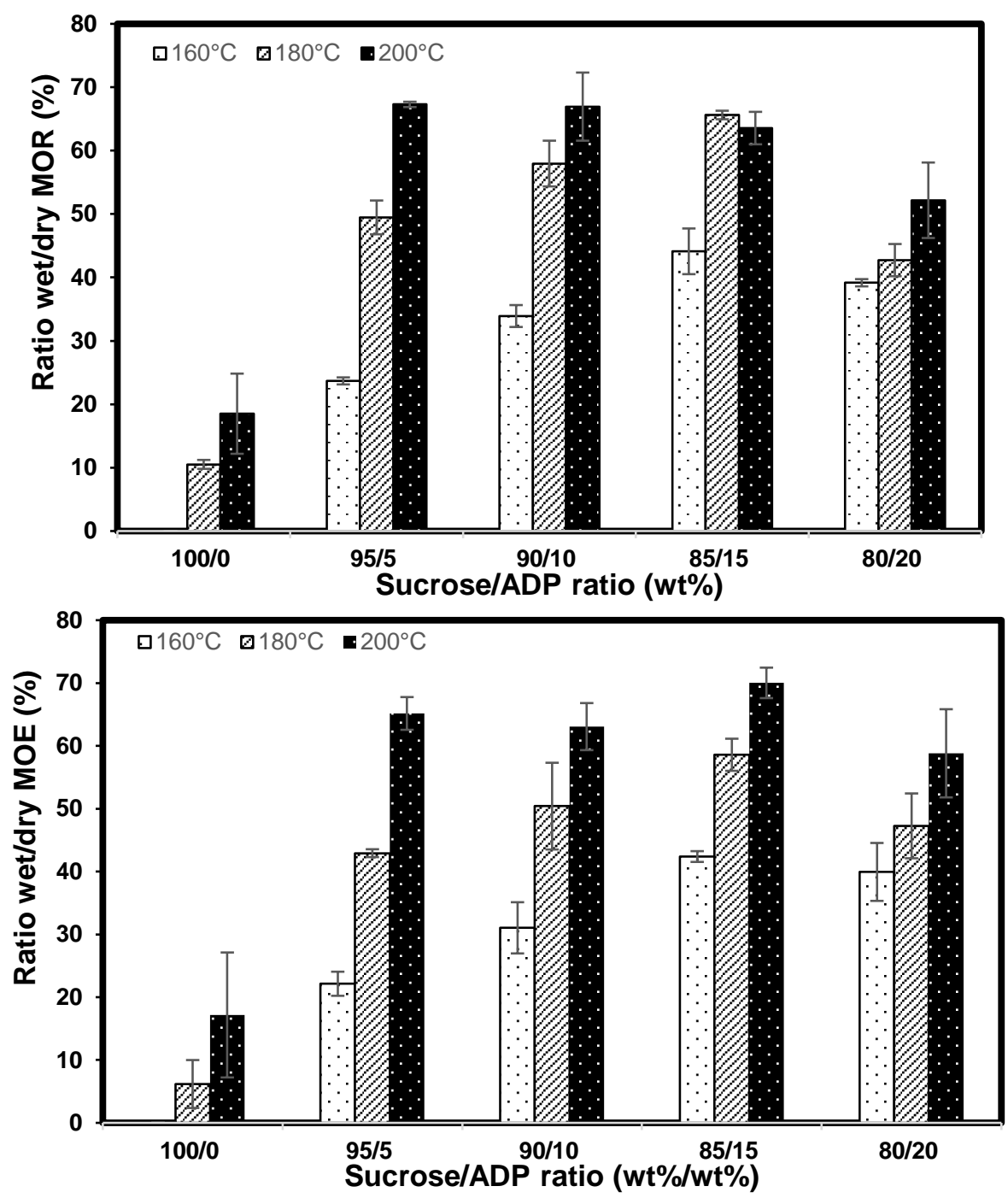

Fig. 3. Ratios of wet/dry MOR and MOE of sucrose-based particleboards made from bamboo. Error bars indicate standard deviations. 
The ratios of the wet/dry MOR values of the particleboards that used only sucrose as adhesive and were pressed at $180{ }^{\circ} \mathrm{C}$ and $200{ }^{\circ} \mathrm{C}$ were only $10.5 \%$ and $18.5 \%$, respectively. Even though the water resistance of the boards was relatively low, it indicated that the particleboard had still sufficient bondability that might be due to short-chain polymers with a large amount of branching with other monosaccharides (Lamaming et al. 2013). In another study, teak particleboard bonded with sucrose as adhesive and pressed at $180{ }^{\circ} \mathrm{C}$ was destroyed after boiling treatment for $2 \mathrm{~h}$ (Widyorini et al. 2016b). These results indicated that, in addition to sucrose acting as adhesive, the chemical components of the raw materials also contributed to the bonding mechanism. Future research is needed to make clear the influence of chemical components of the raw materials to the bonding mechanism of sucrose/ADP adhesive.

Almost all of the particleboards that used ADP and were pressed at 180 to $200{ }^{\circ} \mathrm{C}$ had wet/dry MOR ratios greater than 50\%, though there was a decrease at the sucrose/ADP ratio of $80 / 20$. Interestingly, the wet bending strengths of the particleboards using sucrose/ADP ratios of 95/5, 90/10, and 85/15 and pressed at temperatures of $180{ }^{\circ} \mathrm{C}$ and $200{ }^{\circ} \mathrm{C}$ met the requirement of JIS A 5908 (2003) type 13, i.e., at least $6.5 \mathrm{MPa}$. The resulted particleboards had relatively high-water resistance and could have potential as a furniture material. In general, the wet bending strengths of sucrose/ADP based particleboards that were pressed at $160{ }^{\circ} \mathrm{C}$ were lower compared than other pressing temperatures. Based on this study, to meet the requirements for water-resistant particleboards, at least $180^{\circ} \mathrm{C}$ of pressing temperature was needed. Umemura et al. (2017) showed that the insoluble matter rate of sucrose/ADP materials against boiling water was more than $70 \%$ when pressed at $180{ }^{\circ} \mathrm{C}$ and $200{ }^{\circ} \mathrm{C}$ with the addition of ADP 5 to $20 \mathrm{wt} \%$. Zhao et al. (2019b) found that application of synthesized sucrose/ADP as plywood adhesive resulted the optimum wet shear strength for sample that hot pressed at $170{ }^{\circ} \mathrm{C}$.

Similar to the trends in MOR and MOE, the screw holding strength was very low for particleboard that used only sucrose as adhesive and was pressed at $160{ }^{\circ} \mathrm{C}$ (Table 2). Other particleboards had screw holding strengths greater than $300 \mathrm{~N}$, meeting the requirement of JIS A 5908 (2003) type 13. Notably, more than $60 \%$ of the particleboards had a screw holding strength greater than $400 \mathrm{~N}$, meeting the requirement of JIS A 5908 (2003) type 18 . High screw holding strengths were achieved by particleboards produced at a pressing temperature of $160{ }^{\circ} \mathrm{C}$ with an ADP proportion of at least $15 \mathrm{wt} \%$ or produced at a pressing temperature of $180{ }^{\circ} \mathrm{C}$ or greater with an ADP proportion of at least $5 \mathrm{wt} \%$. Overall, the sucrose-ADP based particleboards made from bamboo had high bonding strengths and the potential to be used in furniture.

Figure 4 shows that the sucrose/ADP ratio and pressing temperature significantly affected the IB strength of the particleboards. As with the other physical and mechanical properties, the IB strength of the particleboard that used only sucrose as adhesive and was pressed at $160{ }^{\circ} \mathrm{C}$ was the lowest, indicating that the greater pressing temperatures are needed if using only sucrose as adhesive. Thermogravimetric analysis by Zhao et al. (2018) showed that sucrose starts to exhibit rapid mass loss at $195{ }^{\circ} \mathrm{C}$, due to caramelization reactions. When the pressing temperature increased to $180{ }^{\circ} \mathrm{C}$ and $200{ }^{\circ} \mathrm{C}$, the IB strength increased to $0.65 \mathrm{MPa}$ and $0.79 \mathrm{MPa}$, respectively. In other studies, the IB strengths of sucrose-based particleboards that were pressed at $180{ }^{\circ} \mathrm{C}$ and made from old oil palm trunk, teak wood, and recycled wood particleboards, were 0.91, $0.11 \mathrm{MPa}$, and $0 \mathrm{MPa}$ (not measurable), respectively (Lamaming et al. 2014; Widyorini et al. 2016b; Zhao et al. 2018). Those results indicated that the bonding mechanisms were affected by many factors, such as pressing time, adhesive content, or even the raw materials used. The chemical 
components of raw materials that synergize with sucrose to produce good bondability and the corresponding bonding mechanisms are interesting topics for future research.



Fig. 4. The IB strength of sucrose-based particleboards made from bamboo.Error bars indicate the standard deviation.

This research also showed that the addition of ADP could reduce the required pressing temperature. By adding $5 \mathrm{wt} \%$ of ADP in the adhesive mixture, the IB strength increased to $1.2 \mathrm{MPa}$ with a $180{ }^{\circ} \mathrm{C}$ pressing temperature, which met the requirement of the JIS A5908 type 18 standard. However, if the pressing temperature was set at $160{ }^{\circ} \mathrm{C}$, at least $20 \mathrm{wt} \%$ of ADP was needed in the adhesive to achieve the same IB strength. The results clearly showed that ADP acted as catalyst, and the pressing temperature significantly affected the reaction. Zhao et al. (2018) showed that when the hot-pressing temperature was equal to or greater than $160{ }^{\circ} \mathrm{C}$, the mechanical properties of particleboards with sucrose/ADP ratios of $85 / 15$ fulfilled the requirement of JIS A5908 type 18 standard.

Interestingly, Fig. 4 shows that with a $200{ }^{\circ} \mathrm{C}$ pressing temperature, the IB strength was not significantly affected by the addition of ADP. However, a slight increase in board properties was observed with increase in ADP content. A possible reason is that sucrose was the main source of bonding strength in this adhesion system. However, the added ADP was responsible for increasing the water resistance properties, as shown by the TS and wet bending strength values. In addition, it was mentioned by Zhao et al. (2019b) that the addition of ADP improved the thermal stability of sucrose at high temperature.

A comparison of the properties of the boards produced in this study and in other related studies is shown in Table 3 . Sucrose could be used as an effective adhesive with high pressing temperatures and longer pressing times (Lamaming et al. 2014, Widyorini et al. 2016b). Results shown in Table 3 indicate that the chemical components of the raw materials influenced the bond strength of sucrose-based particleboard. Addition of sucrose lowered the xylose/arabinose ratio, which indicates the degree of linearity of branching of hemicelluloses (Lamaming et al. 2013). The presence of ADP was supposed to be a catalyst in the sucrose-based adhesive system. Infrared analysis of sucrose-ADP adhesive showed 
peaks that indicated furan rings, carbonyl groups, and dimethylene ether bridges, which were possibly formed by the dehydration of sucrose (Zhao et al. 2018). The addition of ADP promoted the conversion of sucrose to 5-HMF (Sun et al. 2019b). Other reactions that also took place such as hydrolysis of sucrose and ammonium ion, the dehydration of monosaccharides, the Amadori rearrangement, caramelization, and the Maillard reaction (Zhao et al. 2020), continued by the dehydration condensation of furan compounds and Maillard reaction during curing process (Zhao et al. 2019b).

In addition, at high temperatures, hemicellulose and part of cellulose degrade to produce simple sugars and other decompositions products (Widyorini et al. 2005). The sugar components of the raw materials also support the bonding mechanism, while ADP may be acting as a catalyst in the degradation of sucrose and other sugar components. Komariah et al. (2019) stated that addition of ADP improved the bond strength between oil palm trunk particles. It seems that all the decomposition products then polymerize and arrange into a stable network during hot pressing, resulting in good properties of the particleboards.

Table 3. Comparison of the Properties of the Particleboards of this Study and of Other Related Studies

\begin{tabular}{|c|c|c|c|c|c|c|}
\hline $\begin{array}{l}\text { Characteristic of } \\
\text { Particleboard }\end{array}$ & $\begin{array}{l}\text { This } \\
\text { Research }\end{array}$ & $\begin{array}{l}\text { This } \\
\text { Research }\end{array}$ & $\begin{array}{l}\text { Lamaming et } \\
\text { al. (2014) }\end{array}$ & $\begin{array}{c}\text { Widyorini } \\
\text { et al. } \\
\text { (2016b) }\end{array}$ & $\begin{array}{c}\text { Zhao } \\
\text { et al. } \\
(2018)\end{array}$ & $\begin{array}{c}\text { Komariah } \\
\text { et al. } \\
(2019)\end{array}$ \\
\hline Raw material & $\begin{array}{l}\text { Petung } \\
\text { Bamboo }\end{array}$ & $\begin{array}{l}\text { Petung } \\
\text { Bamboo }\end{array}$ & $\begin{array}{l}\text { Old \& young } \\
\text { oil palm trunk }\end{array}$ & $\begin{array}{l}\text { Teak } \\
\text { wood }\end{array}$ & $\begin{array}{l}\text { Recycled } \\
\text { wood }\end{array}$ & $\begin{array}{l}\text { Oil palm } \\
\text { trunk }\end{array}$ \\
\hline $\begin{array}{l}\text { Adhesive/binder/ } \\
\text { catalyst type }\end{array}$ & Sucrose & $\begin{array}{c}\text { Sucrose/ } \\
\text { ADP } \\
(95 / 5)\end{array}$ & Sucrose & Sucrose & $\begin{array}{c}\text { Sucrose/ } \\
\text { ADP } \\
(85 / 15)\end{array}$ & ADP \\
\hline $\begin{array}{c}\text { Adhesive } \\
\text { content }\end{array}$ & (20 wt\%) & (20 wt\%) & (20 wt\%) & $(10 w t \%)$ & (20 wt\%) & (10 wt\%) \\
\hline $\begin{array}{l}\text { Pressing } \\
\text { condition }\end{array}$ & $\begin{array}{l}200^{\circ} \mathrm{C} \\
10 \mathrm{~min}\end{array}$ & $\begin{array}{l}180^{\circ} \mathrm{C} \\
10 \mathrm{~min}\end{array}$ & $\begin{array}{l}180^{\circ} \mathrm{C} \\
20 \mathrm{~min}\end{array}$ & $\begin{array}{l}200^{\circ} \mathrm{C} \\
10 \mathrm{~min}\end{array}$ & $\begin{array}{l}200^{\circ} \mathrm{C} \\
10 \mathrm{~min}\end{array}$ & $\begin{array}{l}180^{\circ} \mathrm{C} \\
10 \mathrm{~min}\end{array}$ \\
\hline $\begin{array}{l}\text { Target density } \\
\left(\mathrm{g} / \mathrm{cm}^{3}\right)\end{array}$ & 0.8 & 0.8 & 0.8 & 0.9 & 0.8 & 0.8 \\
\hline $\operatorname{MOR}(\mathrm{MPa})$ & 13.7 & 14.3 & $13.6 \& 10.7$ & 9 & 25 & 8.9 \\
\hline MOE (GPa) & 3.4 & 4.2 & - & 2.5 & 5 & 2.5 \\
\hline Wet MOR (MPa) & 3.8 & 7.8 & - & 3.8 & - & - \\
\hline $\mathrm{IB}(\mathrm{MPa})$ & 0.8 & 1.2 & $1.9 \& 2.1$ & 0.22 & 1.4 & 0.53 \\
\hline TS (\%) & 11.7 & 9.3 & $15.2 \& 15.9$ & 9 & 9.2 & 5.9 \\
\hline
\end{tabular}

\section{CONCLUSIONS}

1. The interaction of the pressing temperature and the ratio of sucrose to ammonium dihydrogen phosphate (ADP) significantly affected all of properties physical and mechanical properties of the particleboard made from petung bamboo. The addition of ADP decreased the required pressing temperature for producing boards with properties that met the standard. 
2. At $200{ }^{\circ} \mathrm{C}$ pressing temperature, the TS value, bending strength, screw holding strength, and IB strength were not significantly affected by the addition of ADP. However, the WA value and wet bending strength were noticeably affected by the addition of ADP, indicating that ADP can be regarded as an important catalyst to increase the water resistance of the sucrose adhesive.

3. In this research, optimal conditions were achieved with a $180{ }^{\circ} \mathrm{C}$ pressing temperature and a sucrose/ADP ratio of $95 / 5$ (wt $\% / \mathrm{wt} \%$ ). The properties of the particleboard at these conditions were as follows: The TS, WA, surface roughness, MOR, MOE, wet MoR, wet MoE, IB strength, and screw holding strength were 9.3\%, 38\%, $8.48 \mu \mathrm{m}$, 14.3 $\mathrm{MPa}, 4.2 \mathrm{GPa}, 7.8 \mathrm{MPa}, 2.2 \mathrm{GPa}, 1.2 \mathrm{MPa}$, and $412 \mathrm{~N}$, respectively.

\section{ACKNOWLEDGMENTS}

The author thanks Andhika Lazari Giri and Greitta Kusuma Dewi for support in manufacturing and evaluation of the properties of the particleboards.

\section{REFERENCES CITED}

Bamboo Phylogeny Group (2012). "An updated tribal and subtribal classification of the bamboos (Poaceae: Bambusoideae)," Bamboo Science \& Culture: The Journal of the American Bamboo Society 25(1), 1-10.

Bertaud, F., Tapin-Lingua, S. A., Pizzi, A., Navarrete, P., and Petit-Conil, M. (2012). "Development of green adhesives for fibreboard manufacturing, using tannins and lignin from pulp mill residues," Cellulose Chemistry and Technology 46(7-8), 449455.

Chen, F., Jiang, Z., Deng, J., Wang, G., Zhang, D., Zhao, Q., Cai, L., and Shi, S. Q. (2014). "Evaluation of the uniformity of density and mechanical properties of bamboo-bundle laminated veneer lumber (BLVL)," BioResources 9(1), 554-565. DOI: 10.15376/biores.9.1.554-565

Hiziroglu, S., Jarusombuti, S., and Fueangvivat, V. (2004). "Surface characteristics of wood composite manufactured in Thailand," Building and Environment 39(11), 13591364. DOI: 10.1016/j.buildenv.2004.02.004

Hiziroglu, S., and Suzuki, S. (2007). "Evaluation of surface roughness of commercially manufactured particleboard and medium density fiberboard in Japan," Journal of Materials Processing Technology 184(1-3), 436-440. DOI:

10.1016/j.jmatprotec.2006.11.011

Huang, D., Zhou, A., and Bian, Y. (2013). "Experimental and analytical study on the nonlinear bending of parallel strand bamboo beams," Construction and Building Materials 44, 585-592. DOI: 10.1016/j.conbuildmat.2013.03.050

Jeong, B., and Park, B.-D. (2019). "Effect of molecular weight of urea-formaldehyde resins on their cure kinetics, interphase, penetration into wood, and adhesion in bonding wood," Wood Science and Technology 53, 665-685. DOI: 10.1007/s00226019-01092-1

JIS A 5908 (2003). "Particleboards," Japanese Standards Association, Tokyo, Japan.

Komariah, R. N., Miyamoto, T., Tanaka, S., Prasetiyo, K. W., Syamani, F. A., Subyakto, 
Umezawa, T., Kanayama, K., and Umemura, K. (2019). "High-performance binderless particleboard from the inner part of oil palm trunk by addition of ammonium dihydrogen phosphate," Industrial Crops and Products 141. DOI: 10.1016/j.indcrop.2019.111761

Kusumaningtyas, I., Yordaniansyah, H., and Purwanto, T. A. (2016). “Acoustical properties of petung bamboo for the top plate of guitars," Applied Acoustics 112, 123 130. DOI: 10.1016/j.apacoust.2016.05.016

Laemlaksakul, V. (2010). "Physical and mechanical properties of particleboard from bamboo waste," International Journal of Materials and Metallurgical Engineering 4(4), 276-280. DOI: 10.5281/zenodo.1074531

Laemlaksakul, V., and Kaewkuekool, S. (2006). "Laminated bamboo materials for furniture - A systematic approach to innovative product design," WSEAS Transactions on Advances in Engineering Education 3(5), 424-430.

Lamaming, J., Sulaiman, O., Sugimoto, T., Hashim, R., Said, N., and Sato, M. (2013). "Influence of chemical components of oil palm on properties of binderless particleboard," BioResources 8(3), 3358-3371. DOI: 10.15376/biores.8.3.3358-3371

Lamaming, J., Hashim, R., Sulaiman, O., Sugimoto, Sato, M., and Hiziroglu, S. (2014). "Measurement of some properties of binderless particleboards made from young and old oil palm trunks," Measurement 47, 813-819.

DOI:10.1016/j.measurement.2013.10.007

Lei, H., Pizzi, A., Navarrete, P., Rigolet, S., Redl, A., and Wagner, A. (2010). "Gluten protein adhesives for wood panels," Journal of Adhesion Science and Technology 24(8-10), 1583-1596. DOI: 10.1163/016942410X500963

Mahdavi, M., Clouston, P. L., and Arwade, S. R. (2012). “A low-technology approach toward fabrication of laminated bamboo lumber," Construction and Building Materials 29, 257-262. DOI: 10.1016/j.conbuildmat.2011.10.046

Moubarik, A., Allal, A., Pizzi, A., Charrier, F., and Charrier, B. (2010). "Characterization of a formaldehyde-free cornstarch-tannin wood adhesive for interior plywood," European Journal of Wood and Wood Products 68, 427-433. DOI: 10.1007/s00107009-0379-0

Ni, L., Zhang, X., Liu, H., Sun, Z., Song, G., Yang, L., and Jiang, Z. (2016). "Manufacture and mechanical properties of glued bamboo laminates," BioResources 11(2), 4459-4471. DOI: 10.15376/biores.11.2.4459-4471

Nirala, D. P., Ambasta, N., and Kumari, P. (2017). "A review on distribution of bamboos," Life Sciences Leaflets 92, 70-78.

Norström, E., Fogelström, L., Nordqvist, P., Khabbaz, F., and Malmström, E. (2014). "Gum dispersions as environmentally friendly wood adhesives," Industrial Crops and Products 52, 736-744. DOI: 10.1016/j.indcrop.2013.12.001

Sun, S. J., and Zhao, Z. Y. (2018). "Influence of acid on the curing process of tanninsucrose adhesives," Bioresources 13(4), 7683-7697. DOI: 10.15376/biores.13.4.76837697

Sun, S., Zhao, Z., and Umemura, K. (2019a). "Further exploration of sucrose-citric acid adhesive: Synthesis and application on plywood," Polymers 11, 1875. DOI: 10.3390/polym11111875

Sun, S., Zhang, M., Umemura, K., and Zhao, Z. (2019b). "Investigation and characterization of synthesis conditions on sucrose-ammonium dihydrogen phosphate (SADP) adhesive: Bond performance and chemical transformation," Materials 12, 4078. DOI:10.3390/ma12244078 
Tondi, G., Wieland, S., Wimmer, T., Schnabel, T., and Petutschnigg, A. (2012). "Starchsugar synergy in wood adhesion science: Basic studies and particleboard production," European Journal of Wood and Wood Products 70, 271-278. DOI: 10.1007/s00107011-0553-z

Umemura, K., Hayashi, S., Tanaka, S., and Kanayama, K. (2017). "Changes in physical and chemical properties of sucrose by the addition of ammonium dihydrogen phosphate," Journal of the Adhesion Society of Japan 53(4), 112-117. DOI: 10.11618/adhesion.53.112

Umemura, K., Kaiho, K., and Kawai, S. (2009). "Characterization of bagasse-rind particleboard bonded with chitosan," Journal of Applied Polymer Science 113(4), 2103-2108. DOI: 10.1002/app.29704

Umemura, K., Sugihara, O., and Kawai, S. (2013). "Investigation of a new natural adhesive composed of citric acid and sucrose for particleboard," Journal of Wood Science 59, 203-208. DOI: 10.1007/s10086-013-1326-6

Umemura, K., Ueda, T., and Kawai, S. (2012). "Effect of moulding temperature on the physical properties of wood-based moulding bonded with citric acid," Forest Product Journal 62(1), 63-68. DOI: 10.13073/FPJ-D-11-00121.1

Widjaja, E. A. (2000). "Bamboo diversity and its future prospect in Indonesia," in: Proceedings of the Third International Wood Science Symposium, Kyoto, Japan, pp. 235-240.

Widyorini, R., Higashihara, T., Xu, J., Watanabe, T., and Kawai, S. (2005). "Selfbonding characteristics of binderless kenaf core composites," Wood Science and Technology 39. DOI: 10.1007/s00226-005-0030-0

Widyorini, R., Umemura, K., Isnan, R., Putra, D. R., Awaludin, A., and Prayitno, T. A. (2016a). "Manufacture and properties of citric acid-bonded particleboard made from bamboo materials," European Journal of Wood and Wood Products 74, 57-65. DOI: 10.1007/s00107-0150967-0

Widyorini, R., Nugraha, P. A., Rahman, M. Z. A., and Prayitno, T. A. (2016b). "Bonding ability of a new adhesive composed of citric acid-sucrose for particleboard," BioResources 11(2), 4526-4535. DOI: 10.15376/biores.11.2.4526-4535

Widyorini, R., Umemura, K., Septiano, A., Soraya, D. K., Dewi, G. K., and Nugroho, W. D. (2018). "Manufacture and properties of citric acid-bonded composite board made from Salacca frond: Effects of maltodextrin addition, pressing temperature, and pressing method," BioResources 13(4), 8662-8676. DOI: 10.15376/biores.13.4.86628676

Yang, I., Kuo, M., Myers, D. J., and Pu, A. (2006). "Comparison of protein-based adhesive resins for wood composites," Journal of Wood Science 52, 503-508. DOI: 10.1007/s10086-006-0804-5

Zhao, Z., and Umemura, K. (2014). "Investigation of a new natural particleboard adhesive composed of tannin and sucrose," Journal of Wood Science 60, 269-277. DOI: $10.1007 / \mathrm{s} 10086-014-1405-3$

Zhao, Z., Hayashi, S., Xu, W., Wu, Z., Tanaka, S., Sun, S., Zhang, M., Kanayama, K., and Umemura, K. (2018). "A novel eco-friendly wood adhesive composed by sucrose and ammonium dihydrogen phosphate," Polymers 10, 1251. DOI: 10.3390/polym 10111251

Zhao, Z., Sakai, S., Wu, D., Chen, Z., Zhu, N., Gui, C., Zhang, M., Umemura, K., and Yong, Q. (2020). "Investigation of synthesis mechanism, optimal hot-pressing 
conditions, and curing behavior of sucrose and ammonium dihydrogen phosphate adhesive," Polymers 12, 216. DOI:10.3390/polym12010216

Zhao, Z., Sakai, S., Wu, D., Chen, Z., Zhu, N., Huang, C., Sun, S., Zhang, M., Umemura, K., and Yong, Q. (2019a). "Further exploration of sucrose-citric acid adhesive: investigation of optimal hot-pressing conditions for plywood and curing behavior," Polymers 11, 1996. DOI:10.3390/polym11121996

Zhao, Z., Sun, S., Wu, D., Zhang, M., Huang, C., Umemura, K., and Yong, Q. (2019b). "Synthesis and characterization of sucrose and ammonium dihydrogen phosphate (SADP) adhesive for plywood," Polymers 11, 1909.

DOI:10.3390/polym11121909

Article submitted: February 17, 2020; Peer review completed: March 23, 2020;

Revised version received and accepted: May 9, 2020; Published: May 14, 2020.

DOI: 10.15376/biores. 15.3.5072-5086 